\title{
THE PSYCHOLOGY OF THE REFORMER AND THE STAND-PATTER
}

\author{
BY HENRY W. FARNAM \\ Yale University
}

Recognizing our moral right to possess our own literary portrait, the Unpopular Review generously shares with us these excerpts from "The Psychology of Reform" which it published in a recent issue.

\section{THE REFORMER}

The situation which creates the need of reform is usually one in which those who enjoy rights either lack the economic power or the ability or the inclination to use them wisely.

When such a dislocation begins to show itself, certain people of exceptional keenness of perception or sense of justice begin to agitate reform. Sometimes they are those who have suffered some personal wrong from the abuses complained of. Quite as frequently they have no egotistic interest in the matter, but are moved by sympathy with the oppressed, or by patriotism, or by some other altruistic impulse. A man of this type is Kipling's ideal reformer:

. . . who, bred and taught

By sleek, sufficing Circumstance-

Whose Gospel was the apparelled thought,

Whose Gods were Laxury and Chance-

Sees, on the threshold of his days,

The old life shrivel like a scroll,

And to unheralderl dismays

Submits his body and his soul;

He shall forswear and put away The idols of his sheltered house; And to Necessity shall pay

Unflinching tribute of his vows.

He shall not plead another's act, Nor bind him in another's oath To weigh the Word above the Fact, Or make or take excuse for sloth.
The yoke he bore shall press him still, And long-ingrainéd effort goad

To find, to fashion, and futhl

The cleaner life, the sterner code.

But every reform movement contains a great many variants upon this ideal, and occasionally includes some alloys and some counterfeits. Like an army, it has to use different types of fighters adapted to different kinds of work and different stages of development. It is usually preceded by the pioneers or scouts - people of intense conviction, singleness of purpose, and courage. Very often the persecution to which they are naturally subjected develops a certain fanaticism and drives them to extremes. These are the Savonarolas, John Knoxes, Robert Owens, Garrisons, John Browns, and Carrie Nations. A certain amount of fanaticism is often necessary to give them the driving force; it is like the high tension current that spans distance. While their radicalism arouses opposition, it gives what modern parlance calls "good publicity"; it advertises the evils that need reforming. If Samuel Plimsoll had not felt the injustice of the sailor's lot so intensely as to lose his temper in the House of Commons, the merchants shipping act might never have been passed.

The scouts are often followed by the engineers who prepare the way by 
science and study. They furnish the intellectual basis of the movement. They are men of the type of Helper in the anti-slavery movement, or of the committee of fifty in the movement to regulate the use of alcohol. Their work is often unobtrusive and at the time may seem to be of little value, but they lay the foundation on which others will build.

The artillery of the reform movement is represented by the orators and the pamphleteers. They open the way for the final onslaught of the infantry, which marches in when the mass of the people become convinced of the need of reform, and unconsciously become reformers.

The strategist of the reform army is the statesman, who waits until the scouts and the engineers have done their work, and until he has gathered sufficient artillery and infantry to carry the day. Lincoln was preeminently of this type. The real statesman often has to occupy a middle ground, appearing lukewarm to the eyes of the radicals, and radical to the eyes of the conservatives. He has to endure misrepresentation in silence, but it is upon his ability to weigh the different forces involved that the victory depends.

As the reform army increases in numbers it inevitably becomes diluted in quality. The men of conviction are joined by others who are influenced mainly by class interest, or who are swept along by public opinion, or who merely like to be on the winning side. When success is assured, there are not a few whose motives are purely sordid and who take advantage of the public sentiment to feather their own nests. They are the camp followers of the army, and not seldom bring the very word reform into disrepute.

When class interest becomes predominant, reform may turn into revolution.

\section{THE STAND-PATTER}

Vested interests are the greatest obstacle to reform, and there is hardly any institution which is not tied up with such interests. The feudal lords had their estates and their feudal privileges. The Church of Rome had its great investments in ehurch buildings, schools, and monasteries, to say nothing of Peterspence and other sources of income. Slavery had its plantations. The first impulse of the conservative is to charge the reformer with an invasion of the rights of property. 'This was the great argument of the upholders of slavery, but we find it constantly repeated by those who oppose tariff reform, liquor reform, and now even the reform of our extravagant habits in order to finance the war. Anyone who advocates saving or economy is liable to be branded as an enemy of business.

Besides the inevitable reaction of the pocket nerve, another common obstacle to reform is found in the mental inertia (euphemistic for stupidity or laziness) of the great mass of the people. Their favorite argument is that the reformers are undermining the foundation of ethics or politics or society. They are temperamentally Bourbons; they learn nothing and forget nothing. Often they have been infected in early youth with certain doctrines for which no mental serum had been discovered. In our country such a conservative force has been the doctrine of states' rights. This was the intellectual arsenal of the proslavery forces at the time of the Civil war. It reappeared as the enemy of the conservation movement. It cropped up in opposition to the regulation of child labor by the federal government. It blocked for years the reform of our banking system. More recently it has stood in the way of the 
reform of the army, even when the weakness of the militia system was obvious. It was resorted to in such a relatively small matter as the prohibition of the use of poisonous phosphorus in the manufacture of matches. It is before us now in opposition to the prohibition by amendment to the federal constitution of alcoholic drinks.

When the stand-patter is not able to deny the evils which the reformers criticise, he often holds the reformers responsible for those evils. Before the Civil war the slave-owners claimed that the persistency of slavery was due to Garrison and the other Abolitionists, and that if the institution had been left alone, it would have been reformed by the southerners. An able southern statesman has recently maintained this thesis in a book. But the evidence is all the other way. The whole course of slave legislation in the South was in the direction of confirming, not reforming, the institution of slavery. We find a similar argument brought up with regard to the liquor problem, when the prohibitionists are made responsible for aggravating the evils which they criticise. There is of ten this modicum of truth in such contentions, that an active reform movement almost always stiffens the resistance of those who are opposed to it. But some sober judges claim that in both of the instances cited, the violent reform movement did not begin until all prospect for reform from within had vanished, and the tide was setting towards the consolidation, not towards the elimination of the abuses complained of.

Another element in the psychology of the stand-patter, which recurs with remarkable frequency, is the tendency to accuse the reformer of hypocrisy. When the Abolitionists were showing up the evils of slavery, Calhoun and other southern statesmen retorted by pointing out the bad conditions under which factory hands lived and worked in the North, and charged the Abolitionists with being hypocrites. When civil service reform began to be effective, the spoilsmen sneered at it as "snivel" service reform. The liquor interests inveigh against the temperance reformers as holier-than-thous. In fact this charge returns so frequently that it has stimulated an inverted hypocrisy, which is often as far from reflecting the real life of the individual as is the traditional hypocrisy of the Pharisee. There are not a few people who are so afraid of being thought better than they are, that they go to the other extreme and affect to be worse than they are. If hypocrisy is the tribute which vice pays to virtue, inverted hypocrisy is the tribute which virtue pays to vice. The amateur politician likes to seem to be one of "the boys," even when he has little in common with them. The clergyman is pleased to be taken fon a layman; a really temperate man may affect the manners of the barroom in order to show that he is a good mixer; the scholar sometimes poses as a sport.

The insider almost always has one advantage in argument. He is usually better informed regarding his fixd interests than the reformer. The slave owners before the Civil war knew a lot about the social incidents of the slave system which the Abolitionists did not know. The spoilsmen know a lot about practical government which the civil service reformer, as such, does not know. They appreciate the difficulty, when you have selected your good man, of getting him to serve. Hence, the insider is apt to despise the technical blunders of the reformer, and to regard him as visionary and unpractical. On the other hand, the insider is often blind to the broader 
aspects of the question, because he sees so much of the details, and in particular of the loss which would come to him from reform. This has been a striking characteristic of the insider in our public service corporations. Many of them have been so successful in overriding public opinion, that they have over estimated the indifference of the general public. They have not taken to heart Lincoln's: "You cannot fool all of the people all the time."

Enough has been said to show that in all reform movements, whatever the immediate question, there are certain typical mental attitudes. As soon as the slogan of Reform has been sounded, the experienced psychologist can predict with a fair degree of confidence that certain characteristic groups will show themselves on each side of the controversy, and that in the action and reaction of the attack and the defense, certain types of argument and rejoinder will be used.

When reform has accomplished its end in whole or in part, it often creates its own vested interests, its own prejudices, its own conservatives. The reform movement of one generation then crystallizes into reaction in the next.

This tendency of reform to harden into reaction is aided by the fact that the individual reformers, as they grow older, naturally tend to become less receptive to new ideas. The story of their past achievements becomes a legend which they revere, and they cannot always realize that what was real progress in their youth, no longer meets the needs of the times in their old age. . . . Every law which has been passed, every reform which has been carried, is liable to develop abuses or faults which were not realized in the beginning. If the reformers could constantly maintain an open mind, reform might then be a steady, quiet process instead of proceeding by jerks; and revolutions, with their reigns of terror, would be supplanted by quiet evolution. 